\title{
NUORISO KAPITALISMIN "HYISISSÄ VESISSÄ"
}

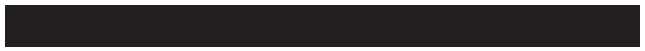

Alain Badiou: La vraie vie. Fayard 2016.

\begin{abstract}
Alain Badiou hauskuutti - tai hämmensi ja ärsytti - esiintymällä syyskuussa 2016 ranskalaisen radiokanavan France Interin ohjelmassa ja sanomalla, että PokémonGO-peli on "korruption korruptiota". Puhe oli Badioun uudesta nuorisoa käsittelevästä kirjasta $L a$ vraie vie ("tosi" tai "oikea" elämä), ja äkkiseltään katsottuna kaikki merkit viittasivat siihen, että nyt vanheneva miesfilosofi vain paheksuu ajanmukaisen elämän huveja ja kantaa huolta nykynuorison tulevaisuudesta muistelemalla kultaisia korruptoimattomia aikoja. Toisella kuuntelemisella - ja lukemalla puheena olleen kirjan - käy kyllä ilmi, että asiat, ainakaan Badioun ajatukset, eivät ole näin yksinkertaisia. Badioun teoksen teesinä nimittäin on, että jos filosofialla koskaan on ollut mitään virkaa - tai jos se pystyy ylipäätään toimimaan - sen tehtävänä ei voi olla mikään muu kuin nuorison "korruptoiminen". Suhteessa tähän korruptoimisen tehtävään PokémonGO ja muut lisätyn todellisuuden pelit ovat ikään kuin toisen kertaluvun korruptiota: ne toimivat filosofian käsitteellisen työn tapaan, siis näennäisesti rikkovat todellisuuden luonnollisuuden ja asioiden jatkuvan kulun, mutta niin, että lopputuloksena on pelkästään pelaajan solmiutuminen yhä tiukemmin kapitalismin verkkoon.
\end{abstract}

\section{PERINTEIDEN LOPUN MYÖNTÄMINEN}

Badioun kirja "oikeasta elämästä" koostuu tämän nuorille eri yhteyksissä pitämistä puheista. Kirja ei pidä sisällään mitään uutta siinä mielessä, että se vaikkapa esittelisi uusia käsit- teitä tai selvittäisi jotakin ilmiötä tavalla, josta Badiou ei olisi puhunut jo aiemmin - kaiken lisäksi se on hyvin lyhyt. Tästä huolimatta kirja on hieno ja tiivis esitys siitä, miksi nuorisoa täytyy ajatella - ja miksi Badiou itse on nuorisolle päätynyt puhumaan.

Badioun kirjasta riippumattakin lienee mahdollista todeta, että yleistä puhetta nuorisosta leimaa käsitysten kaksinaisuus, jonka mukaan nuoret ovat joko levottomuutta herättävä, huolestuttava, paheksuttava ja surkuteltava joukko, joka ei vaikuta koskaan oikein asettuvan paikkaan, jonka sivistynyt ja valistunut aikuinen järjestys heille antaa, tai sitten heistä tulee kohde kaunopuheisille julistuksille nuorista meidän toivonamme ja koko meidän kyyniseen melankoliaan vajonneen edistyksemme pelastajina. Badioulle nämä molemmat käsitykset ovat hankalia. Badioun mielestä nuorisoa koskevan kysymyksen ydin on seuraava: nuoriso on nimitys sille joukolle, joka on "oman eksistenssinsä alussa" ja joutuu siksi erityisellä tavalla kohtaamaan kysymyksen siitä, mihin elämänsä päätyy käyttämään. Kysymys koskee siis nykyisen kapitalistisen järjestyksen aikaansaamia jännitteitä yksittäisen ihmisen elämässä.

Konkreettisimmin tämä jännite syntyy Badioun mukaan siitä, että nuorisolle tai meille kaikille on nykyään tarjolla kaksi polkua: joko "polttaa elämänsä" tai sitten ryhtyä "rakentamaan" sitä. Oleellista on, että nämä molemmat ovat Badioun mukaan yhtälailla tuhoisia teitä: jos jotain siis ylipäätään on tehtävissä, pitäisi pitää huolta siitä, että nuori ei joudu näille kummallekaan jo "aiemmin tallatulle polulle”. Tätä nuorison korruptoiminen kaikessa yksinkertaisuudessaan on: korruptoiminen ei siis tarkoita sitä, että ikään kuin "turmeltaisiin” 
joku lahjomalla taloudellisen edun, välittömän nautinnon tai valta-aseman avulla. Badiou nimittäin aloittaa nuorison puhuttelunsa väittämällä nimenomaan käsitteiden voivan tukea siinä, että elämä ilman näille kolmelle tielle lähtemistä - raha, välitön nautinto ja valta on ylipäätään mahdollinen.

Teoksen nimi viittaa työhön, jota Badiou on tehnyt edellisen kymmenen vuoden aikana seminaareissaan, joissa hän on käsitellyt Platonia ja erityisesti tämän Valtio-dialogia: luentosarjan nimenä oli vuosina 2007-2010 "Pour aujourd'hui: Platon!”. Tämä työ on tallentunut verkossa kiertävien seminaarimuistiinpanojen lisäksi hänen vuonna 2012 julkaisemaansa $L a$ République de Platon -teokseen, joka on yhtäältä Badioun omaperäinen "käännös" Platonin teoksesta ja toisaalta tästä alkutekstistä täysin itsenäinen näytelmäkäsikirjoitus, siis Badioun oma teksti. Tätä tekstiä on käännetty viime vuosina ahkerasti eri kielille ja myös esitetty teattereissa sekä Ranskassa että muualla.

Tarkkaan ottaen ilmaus "tosi" tai "oikea elämä" periytyy Badioun kielenkäyttöön Arthur Rimbaud'lta, tämän runosta "Délires I, Vierge folle, L'Époux infernal" (suomeksi teoksessa Kausi helvetissä), jossa runon ääni parahtaa seuranneensa nautintoa ja hylänneensä kaikki inhimilliset velvollisuudet: "Mikä elämä! Todellinen elämä ei ole täällä - Quelle vie! La vraie vie est absente." Badiou on tarttunut tähän Rimbaud'n säkeeseen ja käsitellyt sitä toistuvasti eri yhteyksissä, sillä hän tulkitsee, että Rimbaud muotoilee siinä erityisellä tavalla "idean mukaiseen elämään" liittyvän paradoksin. Rimbaud puhuu Badioun mukaan nimenomaan nuorison äänellä: se kuinka Rimbaud itse ensin "polttaa elämänsä” Pariisin houkutuksissa, kirjoittaa näiden syövereiden osoittautuessa pohjattomiksi ja alkaa sitten "rakentaa uraa" kolonialistisena liikemiehenä ympäri maailmaa, näyttää juuri sen välitilan, jossa moderni nuoriso enenevissä määrin elää.

Badioun mukaan Rimbaud näyttää esimerkillisesti, kuinka nuoruus on samalla kertaa erityinen vapauden aika ja ehdottomasti taak- se jätettävä vaihe. Elämänvaihe, jonka myötä Rimbaud muutaman vuoden aikana päätyy Pariisin nautintojen ja kärsimysten pyörteistä asekauppiaaksi, on jotain, jonka kaikki joutuvat omassa elämässään käymään läpi: nuoruudesta käsin aikuisuus vaikuttaa olevan sekä nautintojen rajattomuutta että mahdollista valtaa ja taloudellista menestystä. Badioun ajatuksena on, että nämä aikuisen elämän olemukselliset määreet näyttävät sinänsä nuorten itsensä silmin molemmat yhtä mielettömiltä, mutta silti nimenomaan nykymuotoinen kapitalismi pyrkii kaikin keinoin vakuuttamaan, että juuri yksilöllisen menestyksen tie on ainoa mahdollisuus pelastautua elämän välittömältä hukkaamiselta. Oleellista on, että tämän "meritoitumisen" tien mielekkyys tarjotaan ehdottomana: sitä on joko seurattava tai sitten mitään ei jää jäljelle - ja nimenomaan nykyiselle nuorisolle tämä viesti on yhä ehdottomampi. Tätä kautta Badioun ajatus nuorisosta yhdistyy hänen kapitalismianalyysiinsa. Badiou selvittää toki käsitystään kapitalismin nykyluonteesta monessa muussakin tekstissään, mutta tässä teoksessa asia muotoillaan kapitalismin "kaavana": "osta markkinoiden tuotteita jos pystyt" ja "jos et siihen pysty, pysy hiljaa". Näillä muotoiluilla Badiou viittaa muualla esittelemiinsä teeseihin siitä, että kapitalistisen järjestyksen tarjoama elämänmuoto on "elämää ilman ideaa", elämää jonka ennaltamäärättyä ja laskettavissa olevaa jatkuvuutta ei murra mikään.

Rimbaud'lta löytämänsä runon sanaston Badiou yhdistää Platon-luentaansa, joka toimii myös näiden nuorisolle osoitettujen sanojen kontekstina. Badioun teos alkaa lainauksella Platonin Valtio-dialogista, jonka kohdassa 521b Sokrates keskustelee Adeimantoksen kanssa. Alkuteoksen suomennoksessa keskustelu etenee seuraavalla tavalla:

Sokrates: Voitko nyt mainita todellisen filosofian lisäksi mitään muuta elämänasennetta, joka halveksisi poliittista valtaa? / Adeimantos: En tosiaankaan / Sokrates: Ja niiden jotka rakastavat valtaa, ei pidä havitella sitä, sillä 
muuten näiden rakastajien kilpailijat käyvät taisteluun. / Adeimantos: Se on selvä. / Sokrates: Et kai sinä siis määräisi valtion vartijoiksi ketään muita kuin niitä, jotka selvimmin ymmärtävät miten valtiota parhaiten hallitaan, joiden keskuudessa pätevät toisenlaiset kunnianosoitukset ja joilla on oma elämänsä, parempi kuin elämä politiikan palveluksessa? / Adeimantos: En.

Badioun "käännös" tästä kohdasta käsittelee kyllä samaa asiaa, mutta keskustelu ei enää ole sama. Esimerkiksi alkuperäisen dialogin toinen osallistuja, Platonin veli Adeimantos, on muuttunut Badioun käsittelyssä "Platonin siskoksi" Amanthaksi. Myös dialogin sisältö on muuttunut:

Sokrates: Sanopa, tiedätkö mitään sellaista tapaa elää, joka johtaisi hylkäämään rahan ja vallan. / Amantha: Totta kai, sellainen on todellisen filosofin elämä, Sokrateen elämä! / Sokrates: Näinpä. Selvää on, että niiden, jotka rakastavat valtaa, ei pidä sitä saada, koska siinä tapauksessa päätyisimme pelkkään sotatilaan vallantavoittelijoiden välillä. Siksi on välttämätöntä, että se suuri määrä ihmisiä, joita minä en epäröi kutsua filosofeiksi, omistautuvat joka ikinen poliittisen yhteisön vaalimiseen: intressittömät ihmiset, jotka kyllä luonnostaan tietävät, mikä on yhteiseksi hyväksi, mutta jotka tietävät myös, että on olemassa muita palkintoja kuin ne, jotka voi saada vaikutusvaltaisten tehtävien muodossa, ja että on olemassa elämäntapa, joka on paljon parempi kuin poliittisten johtajien elämä. / Amantha: Oikea elämä... / Sokrates: Oikea elämä. Elämä joka ei ole koskaan täysin tavoittamattomissa - eikä koskaan täysin tavoitettavissakaan. (Badiou 2012, 395 ja Badiou 2016, 12.)

Badioun käännös Platonin teoksesta on sikäli uskalias, että hän ei pelkästään käännä teosta perinteisessä mielessä, siis kielitieteellisesti perusteltavissa olevilla tavalla, vaan kääntää tekstin sisältämien ajatusten nykyhetkeen tuomisen mielessä. Teoksen voi hyvin sanoa olevan "uskollinen" Platonin teokselle, mutta selvää on, että mitään yksinkertaisesti näytettävissä olevia vastaavuuksia Platonin Valtion ja Badioun kirjoittaman Platonin Valtion väliltä ei voi löytää.

Edellä esitetyn lainauksen loppu on $\mathrm{Ba}-$ dioun operaatiosta hyvä esimerkki: perinteisesti tätä kohtaa on luettu perusteluna sille, miksi poliittisen yhteisön kannalta paras ratkaisu olisi asettaa sen johtoon eräänlainen "filosofi-kuningas". Tähän lopputulokseen Sokrates vaikuttaa pääsevän yksimielisesti miestenkeskisessä keskustelussaan Platonin veljen Adeimantosin kanssa. Badioun dialogissa Sokrates keskusteleekin Amanthan kanssa ja tulee kyllä nytkin siihen lopputulokseen, että filosofialla on tehtävänsä, mutta tämä ei tarkoita sitä, että filosofien nyt todella pitäisi olla päivänpoliittisia toimijoita. Filosofialla on poliittinen tehtävänsä joka perustuu siihen, että olipa puhuja missä asemassa tahansa ja minkä alan ihminen tahansa, aina kun joku ajattelee, kirjoittaa ja puhuu universaalista, hän tekee filosofiaa. Badioun käännöksessä tämä asia käy Platonin alkutekstiä selvemmäksi: se houkutus, johon Platonin dialogin miesten välisen puheen tulkinnassa on langettu, on mahdollisesti helpompi torjua Badioun dialogille antamassa muodossa.

Tämä Badioun käännös Platonin dialogista toimii siis hänen nuorisolle pitämistään puheista muodostuvan kirjan kontekstina. Kirjan kolmea erillistä lukua yhdistävänä lähtökohtana on ajatus, että nimenomaan "nuoriso", jos joku, kokee kysymyksen oikeasta elämästä omassa ruumiissaan: nuorten täytyy omassa yksityisessä tilanteessaan ratkaista - tai he tulevat aina ratkaisseeksi - sen, miten suhtautua heille tarjottuihin ja aina jo ennalta läpikäytyihin polkuihin.

Kyse ei suinkaan ole vain siitä, että kunkin sukupolven täytyisi jotenkin itsestään selvästi "etsiä oma tiensä", vaan siitä, että nykyisessä tilanteessa kapitalistisen järjestyksen intressi on nimenomaan saada ihmiset aivan tietyille teille, jotka vaikuttavat näennäisen vapailta, ikään 
kuin vanhan maailman sitoumuksista irtipäässeiltä ja vihdoin jokaisen itse valitsemilta. Badioun mukaan tämän silmänkääntötempun logiikka on se, että kapitalismin tarjoama tila käy yksiin yleisen perinteistä irtaantumisen kanssa. Kapitalismi on tietty "tuotannon järjestämisen tapa”, jossa ei itsessään ole mitään symbolisaatiota: kapitalismi on pelkkää perinteen, siis symbolisaation, taakseen jättämistä, jonka jäljiltä meille jäävät vain kapitalismin "hyiset vedet". Badiou lainaa tässä kohtaa pitkään Kommunistista manifestia:

Porvaristo on hävittänyt kaikki feodaaliset, patriarkaaliset, idylliset suhteet kaikkialla, missä se on päässyt valtaan. Se on katkonut säälimättä feodaaliajan kirjavat siteet, jotka sitoivat ihmisen hänen "luonnolliseen esimieheensä", eikä ole jättänyt ihmisten välille muuta sidettä kuin alastoman edun, tunteettoman "käteismaksun". Se on hukuttanut hurskaan haaveilun, ritarillisen innostuksen ja poroporvarillisen kaihomielisyyden pyhät väreet itsekkään laskelmoinnin jääkylmään veteen. [...] Porvaristo on repinyt perhesuhteelta sen liikuttavan tunnelmallisen verhon ja muuttanut sen pelkäksi rahasuhteeksi. Porvaristo on osoittanut, miten raaka voimanilmaus, jota taantumukselliset niin suuresti ihailevat keskiajassa, saa veltosta laiskuudesta sopivan täydennyksensä. Porvaristo on ensi kerran osoittanut, mitä ihmisen toiminta voi saada aikaan. Se on tehnyt ihmetöitä, jotka ovat kokonaan toisenlaisia kuin Egyptin pyramidit, Rooman vesijohdot ja goottilaiset tuomiokirkot; se on suorittanut retkiä,jotka ovat aivan toisenlaisia kuin kansainvaellukset ja ristiretket. [...] Jatkuvat mullistukset tuotannossa, kaikkien yhteiskunnallisten suhteiden alituinen järkkyminen, ainainen epävarmuus ja liikunta erottavat porvariston aikakauden kaikista muista. (Valitut teokset 1-6, osa 2, 326.)

Badioun ajatuksena on, että juuri nuorisolle tämä "porvariston aikakausi" käy ilmi kaikkein selvimmin: yhtäältä kaikki edistys ajaa perinteiden lopun asiaa eikä mitään valmista ratkaisua ole tarjolla ja toisaalta nimenomaan tässä tilanteessa kipuileminen, siinä tehtävät ratkaisut ajavat kapitalismin asiaa. Kun ”perinteen maailman" hallitseva teesi on "Elä tämän idean kanssa, älä minkään muun!" tai” Samastu johonkuhun sinua vanhempaan!", nyt teesinä on Badioun mukaan seuraava: "Ole ihmiseläin, joka on täynnä pieniä haluja ja jolla ei ole mitään ideaa.” (Badiou 2016, 95.) Edistyksellinen ajattelu koettaa vakuuttaa meidät siitä, että todella olemme vapaita ja että mitään sitovia eroja ei ole enää olemassa - siis että ne kuuluvat menneeseen, ajattelulla tavoittamaan aikaan - ja että juuri siksi me nyt olemme vapaita, tai että vähintäänkin tämän päivän nuoriso on vapaa.

Oleellista on, että erilaiset yhteiskunnalliset sidokset vaikuttavat kuitenkin edelleen yhtälailla voimakkaasti, tuottavat tunteita, voimia ja pelkoja, ja että ainoa tekijä,joka modernissa tilanteessa puuttuu, on eksplisiittinen usko näitä erotteluja oikeuttaviin perusteisiin, siis suhde ideoihin. Tämä menneen maailman uskomuksista vapautuminen ei kuitenkaan johda vapauteen vaan pelkästään siihen, että yhteiskunnallisen elämän sidokset jäävät kokonaan vaille symbolista käsittämisen mahdollisuutta. Badiou analysoi, että tässä tilanteessa tarjolla on kaksi vaihtoehtoa: i) Yhtäältä kaikki modernit ongelmat, ristiriidat ja kriisit näyttävät oikeuttavan tietyn rajattoman "länsimaiden halun", joka tarkoittaa sitä länsimaista edistyksellistä projektia, jonka - olipa se sitten perinteistä valistusajattelua, eettis-taloudellista liberalismia tai porvarillista feminismiä - ajatellaan korjaavan asiat ja jonka puute halutaan korjata niin Euroopassa kuin kaikkialla muuallakin hinnalla millä hyvänsä, vaikka äärimmäisen väkivallan avulla. ii) Toisaalta tarjolla on tietty konservatiivinen ja reaktiivinen "paluu symbolisaatioon". Tällöin puhutaan erilaisista yrityksistä palauttaa jokin mennyt järjestys uskonnollisiin, kansallisiin tai alkuperäisiin yhteisöihin vetoamalla.

Nuoriso on Badioun mielestä erityisessä asemassa siinä, että se ei itsestään selvästi 
myönnä kumpaakaan näistä teistä vaan tyypillisesti esiintyy aina kussakin ajassa näistä teistä kieltäytymisen merkkinä. Koska kyse on nimenomaan perinteestä kieltäytymisestä, tälle eleelle ei koskaan ole tarjolla mitään valmista muotoa. Siksi nuorison tilannetta luonnehtii kaksi houkutusta. Yhtäältä nuoriso päätyy tekemään asioita ja keksimään elämänmuotoja, joita motivoi vapautuminen perinteen järjestyksestä. Badioun mukaan kyse on "välittömän elämän intohimosta, passiosta”, jossa elämä, kuten nuorella Rimbaud'lla, tarkoittaa kaikkien perinteen esteiden ja rajojen ylittämistä "todellisen" ja "vapaan" nautinnon tavoittamiseksi ja tällaisen projektin osoittautumista oman elämän kannalta mahdottomaksi. Toisaalta nuoriso päätyy realisoimaan omat kykynsä yhteiskunnan tarjoamien mahdollisuuksien puitteissa. Jos näistä houkutuksista ensimmäinen tarkoittaa elämänsä "polttamista", jälkimmäinen tarkoittaa sen "rakentamista", "menestymisen intohimoa". Kun jälkimmäinen siis on ikään kuin täynnä mahdollisuuksia, täynnä tulevaisuutta, ensimmäinen ruumiillista sitä, että mitään ei enää ole tarjolla:"No future!"

\section{KORRUPTION TEHTÄVÄ TÄNÄÄN?}

Kysymys nuorisosta kiinnostaa Badiouta nimenomaan siksi, että siinä kiteytyy ristiriita, jonka ihmiset kapitalismin nykymuodon puitteissa eläessään joutuvat kohtaamaan. Badioun tarkastelema nuoriso on näin ollen historiallinen ilmiö. Kyse on nuorisosta juuri tänään. Badioun mukaan nykyisen nuorison tilannetta luonnehtii kolme piirrettä.

Ensinnäkin perinteeseen kuuluneesta aikuisuuden initiaatiosta on päästy eroon. Badiou selvittää, että aikuisuus on pitänyt aina sisällään ajatuksen aikuisuuteen siirtymisestä, nuoruuden lopusta. Tästä siirtymästä on toki enemmän tai vähemmän selviä esimerkkejä, kuten avioliitto, asepalvelus tai taloudellinen riippumattomuus, mutta oleellista on, että nämä kaikki initiaatiot kuuluvat vanhaan, perinteiden maailmaan, jos- ta vapautuminen määrittää nimenomaan tämän ajan nuorisoa. Oleellista on, että kyse on emansipaatiosta: initiaatio on ollut aina vallankäytön erityinen muoto. Toiseksi Badiou esittää, että nykynuorison tilaan vaikuttaa vanhuuden roolin muutos. Badiou selvittää teoksessaan myös itseensä 80-vuotiaana "vanhuksena" viitaten - että vanhuudella ei enää merkitystä, joka sillä on perinteisesti ollut. Tässäkin suhteessa nuoriso todella on vapautunut: yhteiskunnan "vanhat" eivät enää voi säilyttää arvovaltaansa ja asemaansa pelkän vanhemmuutensa oikeuttamana. Kolmanneksi nykyisen nuorison tilannetta määrittää ainakin näennäinen luokkaerojen liudentuminen. Badiou selvittää, miten on itsestään selvää, että nykyisen nuorison tilanne on muutaman vuosikymmenen takaiseen tilanteeseen nähden täysin erilainen: koskaan luokkaerot eivät ole olleet taloudellisessa tai sosiaalisessa mielessä tai perinteisessä merkityksessään niin näennäisen pieniä kuin nykyään.

Vaikka kaikki nämä piirteet ovat ainakin ensisilmäykseltä osa yleisempää emansipaatiota, ne ovat Badioun mukaan viime kädessä nimenomaan nuorison kohtaamien vaikeuksien ytimessä.Initiaation katoaminen johtaa siihen, että nuoruuden ja aikuisuuden määritykset murentuvat perinteisessä muodossaan. Tämän hankaluuden vaikutukset ovat sukupuolittuneita: poikien ja miesten initiaation puute vaikuttaa johtavan ikuisesti jatkuvaan nuoruuteen, kun taas tytöillä ja naisilla tuloksena on erityinen "aikaistettu aikuisuus", se että tytöt ovat ikään kuin aikuisia ennen aikuisuutta. Nämä ilmiöt sopivat Badioun mukaan kapitalistisen järjestyksen intresseihin paremmin kuin hyvin: miesten ikuinen poikamaisuus tarkoittaa ihanteellista kuluttajuutta, koko iän kestävää uusien lelujen hankkimista, kun taas naisten "vapautuminen" tuo optimaalisen lisän työvoiman markkinoille. Nuoruuden ja vanhuuden perinteisten roolien ja luokkaerojen katoaminen johtaa puolestaan siihen, että nuorisolta tuntuu ikään kuin puuttuvan sen määritykseen kuuluva "vastapaino": kun se yhteiskunnallisten totuuksien vartijan rooli, joka 
ehkä vielä 60-luvullakin liitettiin vanhuksiin, on kadonnut, ja kun luokkaeroihinkaan vetoaminen ei enää ole mahdollista, nuoriso vaikuttaa Badioun mukaan hahmottomalta ja siksi pelottavalta voimalta. Badiou väittää, että nuoriso pelottaa nimenomaan poliittisena voimana - koska "niistä" ei voi sanoa mitään yleistä, nuoriso on ihmisten hallinnan näkökulmasta arvaamaton ja pelottava. Nuorisolla joko on tulevaisuus, "toivo" ja edistyksellisen historian kipinä tai sitten se oirehtii, vikuroi ja sairastaa. (Badiou 2016, 34.)

Kysymys nuorisosta ei siis ole Badioulle mikään ylihistoriallinen ilmiö vaan se liittyy siihen "a-symboliseen sotatilaan", jota kapitalismin meille antama tila on (Badiou 2016, 77). Kapitalismin tilassa ainoa mahdollisuus on tehdä omasta olemassaolostaan eli toisin sanoen omasta ruumiistaan "menestyvä", "meritoitunut" ruumis. Käskynä on myydä ruumiinsa markkinoille ja pysyä hiljaa. Kapitalismin tarjoama tie vie toimimaan ikään kuin elämällä omana "urana" olisi jokin mieli. Tässä mielessä oma yksilöllinen ja omiin nimiin luettavissa oleva menestys toimii ikään kuin "ei-mielen tulppana", puutteen korvikkeena. (Badiou 2016, 73).

Badioun kuvaus ei siis ole normatiivinen vaan yritys kuvata sitä, millaisia rakenteellisia voimia tässä nuorison jännitteisessä tilassa vaikuttaa. Kyse on nuorison sukupuolittuneista representaatioista, ei mistään "todellisuudesta" näiden representaatioiden takana. Hän viittaa tasoon, jolla kulttuuri - jos asian näin voi yksinkertaisuuden nimissä ilmaista - tai meidän symbolinen järjestelmämme toimii ja jolla subjektin kohtaama väkivalta tapahtuu. Totta kai on olemassa "toisia" olemassaolon tapoja, jotka eivät - olivatpa ne tulosta yksilöiden paoista tai vaikkapa kollektiivisesta vastarinnasta ja keksimisestä - jäännöksettä sovi symbolisen järjestelmän tarjoamiin re-presentaatioihin. Tällaiset olemassaolon tavat kuitenkin syntyvät ja kamppailevat näiden yleisten rakenteiden puitteissa. Badioun näkökulmasta on oleellista tavoittaa, että puhe "toisista" olemassaolon tavoista on sikäli tyhjää, että pyrkimys ulos perinteistä on nimenomaan kapitalismin oma logiikka. Siksi uusien olemassaolon muotojen luominen ei voi lähteä liikkeelle yksinkertaisesta perinteiden mukaisen symbolisen järjestyksen vastustamisesta: toki näin voi tehdä, mutta tällöin ei päädytä tekemään mitään sellaista, mikä eroaisi siitä, mitä moderni kapitalismi itsessään jo tekee. Tässä suhteessa kysymys nuorisosta on tärkeä: kysymys siitä, missä aikuisuus alkaa, koskee tarkkaan ottaen sitä ratkaisua, joka tuottaa itsesäätelyyn kykenevän subjektin. Tämän ratkaisun suhteen filosofialla on Badioun mukaan tehtävä: sen täytyy Badioun sanoin "auttaa" siinä, että kysymys nuorisosta "palautetaan totuuksiin" (Badiou 2016, 81). Jacques Lacania lainaten Badiou esittää, että filosofian tehtävänä on pitää huolta siitä, että nuorison ruumiita ei laiteta "hyvien" (jotka siis ovat sekä esineellisiä kauppatavaroita että moraalisia hyviä asioita) "palvelukseen".

Mitä filosofia voi sitten tehdä? Badiou on siinä mielessä erityinen ajattelija, että vaikka hän ei missään nimessä puolusta filosofian poliittisuutta, tai kaikkein vähiten poliittista filosofiaa tai filosofiaa ylipäätään sikäli kuin sillä tarkoitetaan filosofiaa akateemisena tieteenä, hänellä on tähän kysymykseen eksplisiittinen vastaus. Toisaalla Badiou on esittänyt, että "filosofian varsinaisena tehtävänä ei ole tuottaa universaaleja totuuksia vaan pikemminkin tehdä mahdolliseksi niiden kokoava vastaanottaminen muokkaamalla ja muovaamalla totuuden kategoriaa" (Badiou 1997, 158). Badiou väittää, että filosofian tehtävänä on saada esiin "universaalin ehdot", jotka eivät ole käsitteellisiä alkuperänsä eivätkä päämääriensä suhteen. Tämä tarkoittaa lyhyesti sanottuna sitä, että universaali ei merkitse mitään viimekätistä merkitystä tai perustavaa rakennetta ymmärryksen piirissä tai transsendentaalisena vaan pelkästään sellaista "immanenttia poikkeusta", jonka tarkasteleminen voi lähteä liikkeelle vain tapahtumasta, jossa asioiden jatkuva kulku katkeaa ja syntyy 
singulaari tilanne, jonka jälkeen paluuta sitä edeltävään tilanteeseen ei ole.

Filosofia ei voi olla poliittista siinä mielessä, että se, kuten Hannah Arendt esitti, hahmottelisi ihmisen olemukseen kuuluvaa poliittisuutta hämmästyttävänä kykynä arvostelmien tekemiseen ja toimintaan julkisessa tilassa. Tällöin ei nimittäin Badioun mukaan lopulta tehdä mitään muuta kuin surraan sitä, että todellinen päivänpolitiikka ei koskaan vaikuta täysin vastaavan tuota kykyä, sillä vaikka ihmiset luonnostaan kykenisivät todelliseen demokratiaan, he eivät koskaan tunnu todella toimivan tämän kyvyn mukaisesti (Badiou 1998, 133). Badiou ajattelee, että toiminta, tapahtuma, turvallisen asioiden kulun murtumat, ovat aina ensisijaisia. Filosofian suhde politiikkaan muodostuu siitä, että täytyy olla jokin diskurssi, jonka avulla tai jonka tukemana tapahtuma on mahdollista käsittää. Badioun mukaan filosofit tai filosofia eivät saa aikaan tapahtumia tai synnytä totuuksia, mutta ajattelu on muutoksen paikka siksi, että ilman sen luomia käsitteitä tapahtumasta ei jää jäljelle mitään. Tämä ei kuitenkaan tarkoita sitä, että yksittäinen ihminen esimerkiksi oman arvostelukykynsä turvin näkisi yhtäkkiä asiat toisin. Käsitysten muutoksen saa aikaan subjektin voima, jota kyllä voi sanoa ajatteluksi, mutta ei suinkaan yksilöllisen kyvyn vaan sanaston, puheen ja käsitteellisen perinteen mielessä. Tällöin subjekti ei ole mikään vahvalla omatunnolla tai valistuneella arvostelukyvyllä varustettu kyvykäs erityisyksilö vaan tekijä,joka ruumiillistaa tietyn tapahtuman aikaansaaman totuuden, olipa tämä tekijä sitten yksittäinen ihminen, toimijoiden yhteisö tai instituutio. Subjekti ei anna tapahtuman vaikutuksen häipyä, ei mukaudu vaan ylläpitää tapahtuman tuottamaa muutosta, ruumiillistaa sen.

Kuten jo sanottua, Badioun mukaan nuorison suhteen filosofian on oltava korruptoivaa: kyse ei ole mistään nuorison villitsemisestä tai hallitsemisesta vaan nuorison tilanteessaan - eli "elämänsä tuhlaamisen" ja sen "rakentamisen" välissä - tekemien ratkaisujen universalisoimisesta, niiden "singulaarien totuuksien polkua seuraten”. Ilman tällaista käsitteellistä tukea "nuorison" tekemiset, olivatpa ne sitten uudenlaisten huvittelujen, nautintojen, turhautumisten tai yhdessäolon muotojen keksimisiä, jäävät kohteiksi moralisoinnille, ihastelulle ja paheksunnalle tai sitten valistuneisuudestaan huumaantuneiden sosiologien neutraaleille havainnoille, joiden johtopäätöksenä on lopulta ainakin rivien välissä se, että "onneksi nuoruuden hullutukset kuitenkin menevät aina ohi”.

Badioun kohdalla voisi tietysti kysyä, mikä tarve vanhalla filosofilla on naureskella julkisuudessa nuorison tai lasten peleille. On toki varmasti selvää, että tekniikkaan olisi etsittävä jokin muu suhde kuin asioista irtisanoutuva paheksunta tai näennäisen innostunut puhe "synnynnäisistä" diginatiiveista, mutta ovatko pelit todella pelkkää elämänsä polttamista, joka täytyy pystyä jättämään taakseen? Ottaen huomioon sen, kuinka suorasanaisesti Badiou kaikkialla pyrkii selventämään eroa hallitsevan isän ja opettajan välillä, voisi ajatella, että kyllä nuoret saavat Badioun puolesta pelata sydämensä kyllyydestä - siihen ei ainakaan vanhenevalla miesfilosofilla ole mitään sananvaltaa. Ehkä Badioun PokémonGO:ta koskeva naurahdus tarkoittaa pelkästään sitä, että vaikka kenelläkään ei todella voi olla valtaa suhteessa siihen, missä tapahtumat syntyvät - ne voivat nimittäin syntyä hyvinkin pelien "lisäämässä" todellisuudessa - kaiken aikuisen valistuksen varjoissa tapahtuvan on kuitenkin pystyttävä ruumiillistumaan totuudeksi, ja tämä ei Badioun mielestä tapahdu ilman käsitteiden, vanhojen ja uusien, tukea.

\section{- ARI KORHONEN}

\section{KIRJALLISUUS}

Alain Badiou(1997) SaintPaul. Fondation del'universalisme. PUF. (Suomennos Janne Porttikivi, Apostoli Paavali. Universalismin perustaja. Gaudeamus 2011). Alain Badiou (1998) Abrégé de métapolitique. Seuil. Alain Badiou (2012) La République de Platon. Fayard. Alain Badiou (2016) La vraie vie. Fayard 